\title{
In Vitro Study Regarding the Biomechanical Behaviour of Bone and Periodontal Splints
}

\author{
I.Model validation
}

\author{
RALUCA MARIA VIERIU ${ }^{1}$, OANA TANCULESCU ${ }^{1 *}$, FLORENTINA MOCANU $^{2 *}$, SORINA MIHAELA SOLOMON $^{1}$, \\ IOAN GABRIEL SANDU ${ }^{3,4}$, CARMEN SAVIN ${ }^{1}$, DANA GABRIELA BOSINCEANU ${ }^{1}$, IULIA CATALINA SAVEANU ${ }^{1}$, \\ MIHAELA SALCEANU ${ }^{1}$, ALINA MIHAELA APOSTU ${ }^{1}$, ADRIAN DOLOCA ${ }^{1}$ \\ ${ }^{1}$ Grigore T. Popa University of Medicine and Pharmacy, Faculty of Dental Medicine, 16 Universitatii Str., 700115, Iasi, Romania \\ ${ }^{2}$ Gheorghe Asachi Technical University of Iasi, Faculty of Mechanical Engineering, 71 D. Mangeron Blvd., 700050, Iasi, Romania \\ ${ }^{3}$ Gheorghe Asachi Technical University of Iasi, Materials Science and Engineering Faculty, 53A D. Mangeron Blvd., 700050 Iasi, Romania \\ ${ }^{4}$ Romanian Inventors Forum, 3 Sf. Petru Movila St., Bloc L11, III/3, 700089 Iasi, Romania
}

This paper is part of a larger study that aims to evaluate the biomechanical behaviour of mandibular bone and periodontal splinting systems subjected to different occlusal forces by means of electric resistive tensometry (ERT). The research was based on the following premise: the degree of bone resorption and periodontal type of splint influence the deformation of the mandibular bone. The study was conducted in two stages: first, the validation of the mandibular dental arch model, which is the subject of the present article, and second, the evaluation of mandibular bone strain in case of different types of bone loss and periodontal splints, which is the subject of a second article.

Keywords: mandibular model validation, bone strain, electric resistive tensometry, Periotest

In the context of periodontal disease, occlusal forces can exacerbate a pre-existing periodontal lesion when they exceed the resistance threshold of a compromised epithelial attachment [1-4]. Periodontal disease and occlusal trauma occur predominantly in the anterior region of the mandible. Although occlusal forces may be lower in this region than other areas of the mandible, deformations may be larger as the bone size is smaller $[5,6]$. In the effort of properly distributing the occlusal load, different types of periodontal splints are employed.

An important aspect in choosing the periodontal splint type is the mechanical interaction between the materials used and the dento-periodontal substrate [7,8]. There is limited literature on the impact of bone resorption and periodontal immobilization on the biomechanical response of bone-tooth-periodontium complex. Therefore the use of immobilization and the choice of its type remains a difficult decision for practitioners. Several methods can be used to clarify these aspects, each of which presenting advantages, disadvantages and limitations: the photoelasticity method, the resistive electric tensometry method, mechanical compressive and tensile strength tests, and the finite element method [9-11]. Regardless of the method, when a mandibular model is intended to simulate different clinical situations, choosing the right material for replicating the alveolar bone is a decisive aspect. This material must be isotropic, even though the bone is not a homogeneous structure, and must exhibit mechanical and elastic properties similar to the mandibular bone.

This paper is part of a larger study that aims to evaluate the biomechanical behaviour of anterior mandibular bone and periodontal splinting systems subjected to different occlusal forces by means of electric resistive tensometry (ERT). ERT represents a non-destructive method for measuring the deformations (strains) of a mechanically loaded object with a resistive electrotensometric transducer (strain gauge - $\mathrm{SG}$ ) which transforms the mechanical deformation variations in electrical resistance variations $[12,13]$. Previous research have measured bone strain using strain gauges at the level of dental supporting structures and around implants [14] during occlusal loading in vitro and in vivo [15] and ex vivo, on cadavers with natural teeth after implant insertion supporting unsplinted and splinted fixed prostheses [16]. Indirect measurements have also been done on mandible replicas made of autopolymerized acrylic resin [16] and epoxy resin [17].

The research was based on the following premise: the degree of bone resorption and periodontal type of splint influence the deformation of the mandibular bone. The study was conducted in two stages: first, the validation of the mandibular dental arch model, which is the subject of the present article, and second, the evaluation of mandibular bone strain in case of different types of bone loss and periodontal splints, which is the subject of a second article. 


\section{Experimental part}

Materials and methods

The dumping effect of the periodontium, tooth displacement and bone strain were evaluated with Periotest device, mechanical comparator and strain gauges respectively. Six acrylic mandibular models, each with 8 teeth, were tested for four variables: (i) occlusal load $(30 \mathrm{~N}, 50 \mathrm{~N}, 100 \mathrm{~N}, 150 \mathrm{~N}$ ); (ii) bone status (without and with bone loss); (iii) mandible surface (buccal/lingual aspect of the bone); (iv) load distribution (central incisors and incisal group); (v) tooth (central incisor - CI and lateral incisor - LI).

\section{a. Teeth selection}

Forty-eight mandibular teeth, from the first right premolar to first left premolar, were selected, six of each type in order to obtain six mandibular models. Teeth were extracted due to periodontal or orthodontic reasons (the study was conducted with the agreement of the ethics committee of Grigore T. Popa University of Medicine and Pharmacy, Iasi, no. 8670). The selected teeth had the mesial-distal, buccal-oral, and cervical-occlusal dimensions of approximately equal dimensions, accepting a variation of maximum $10 \%$ [12].

\section{b. Obtaining the mandibular models}

An edentulous human mandible from Human Anatomy Department of the University was used as reference for curvature and position of the teeth, but also for reproducing the anatomy of the anterior part of the mandible. An impression of the mandible was taken with condensation silicone (Zetaplus Putty, Zhermack, batch No. 192139) (Fig. 1) and used as a conformer for mandibular model (Fig. 2). A pink wax modelling roller (Morsa Dental, Germany, Lot No: DM000147VA804) was made using the silicon conformer (Fig. 3). After the insertion of all the teeth, respecting the inclination of longitudinal axes and the interdental contact points, an impression of the coronal part of the teeth was taken with the same condensation silicon to obtain a guide to standardize the position of the teeth (Fig. 4).

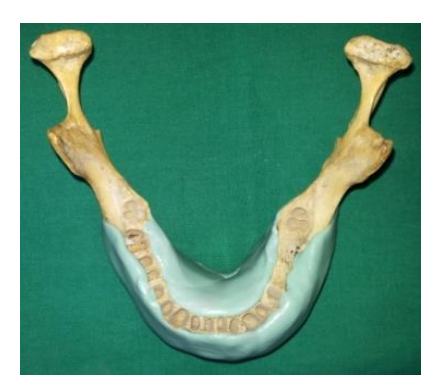

Fig. 1. Impression of the mandible

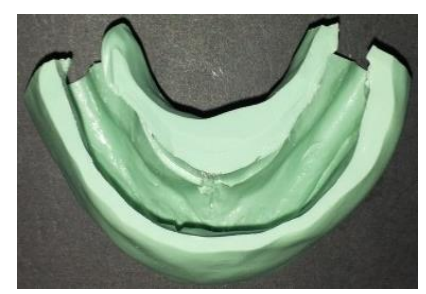

Fig. 2. The conformer for mandibular model

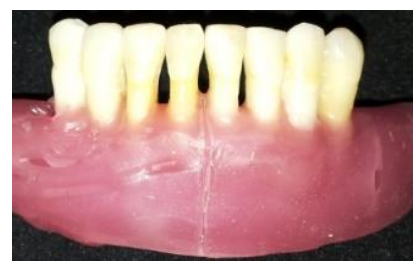

Fig. 3. Teeth positioning according to the arch curvature - buccal vie

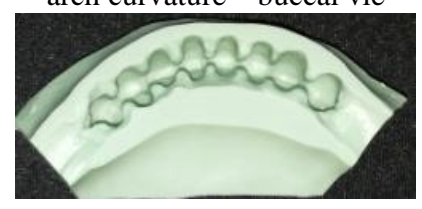

Fig. 4. The silicone guide 
After the disengaging from the wax roll, the root surfaces were cleaned and covered with a layer of calibrated green wax of $0.3 \mathrm{~mm}$ thickness (KARL BERG Dental, Germany, batch no.: 42731313) to replicate the periodontal ligament space (Fig. 5). Then the teeth were inserted into the silicone coronary guide and the roots were isolated using an isopropanol-based substance (Morsa Dental, Germany, lot no.: L2040030-1).

A self-curing acrylic resin was used as material for mandibular bone substrate, with the powder to liquid ratio of 3 to 1.5 (Duracryl Plus, Spofa Dental, Czech Republic, No. Batch: 2373741) [22]. After the acrylate setting, the molten part has been removed from the conformer and then the teeth were removed from the mandibular models and cleaned. Material surpluses were removed and the mandible's external aspect was smoothed using an electric micromotor (Saeyang Marathon Escort III) (Fig. 6).

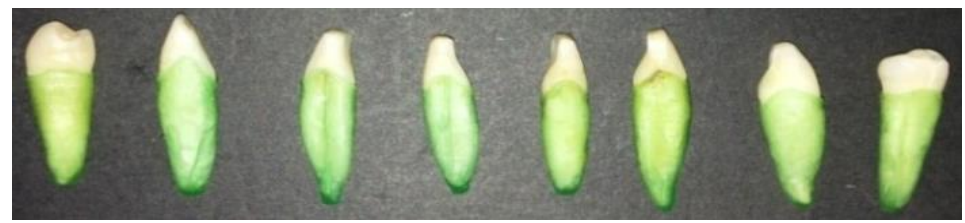

Fig. 5. Roots covering with a $0.3 \mathrm{~mm}$ calibrated layer of wax

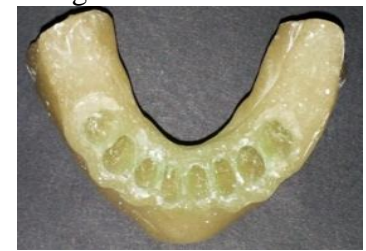

Fig. 6. Acrylate mandible model after tooth removal

A fluid condensing silicone (Zetaplus Light, Zhermack, batch No. 192139) was inserted into the dental alveoli to reproduce the periodontal ligament. The teeth were placed in the alveoli and the excess material was removed before the material setting time was over.

\section{c. Selecting and placing the strain gauges}

Strain gauges (SG) (EA-06-240LZ-120/E, Micro-Measurements Group, Vishay, Batch No.: R-A59AF524) with 6 $\mathrm{mm}$ length and $2 \mathrm{~mm}$ width were selected to quantify the deformations of the bone. Their electrical resistance was 120 $\pm 0.03 \Omega$ at $24^{\circ} \mathrm{C}$.

Six strain gauges were applied on each of the six mandibular models, oriented on the coronal-radicular axis: three on the buccal surface (SG 1 - right lateral incisor/RLI, SG 2 - left central incisor/LCI, SG 3 - left canine/LC) and three on the lingual surface (SG 4 - LC, SG 5 - LCI, SG 6 - RLI).

After degreasing and abrasion, the strain gauges were bonded along the long axis of each tooth, at $5 \mathrm{~mm}$ apical to the superior edge of the acrylate (corresponding to the alveolar margin) to allow the acrylate milling and simulation of bone resorption. The strain gauges were protected with a polyurethane lacquer (M-coat, Micro-Measurements Group, Vishay, Lot No. 1694). Next, the tensile conductors were connected to the tensiometric transducers, and mechanical and electric verification was done. The final appearance of the samples before mechanical testing is shown in figure 7 .

Two strain gauge bridges P3 model (Vishay) were used for recording the specific strains measured by strain gauges (Fig. 8).

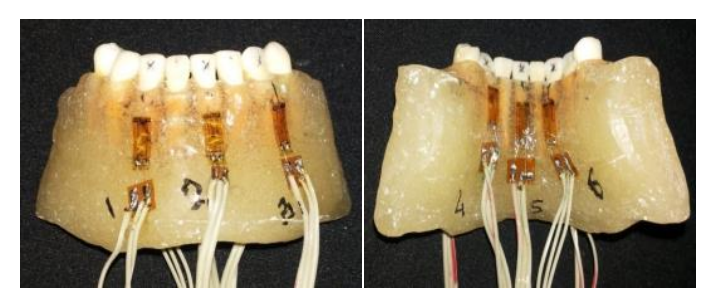

Fig. 7. The final aspect of models after application of the strain gauges ( $\mathrm{a}$ - buccal view; $\mathrm{b}$ - oral view)

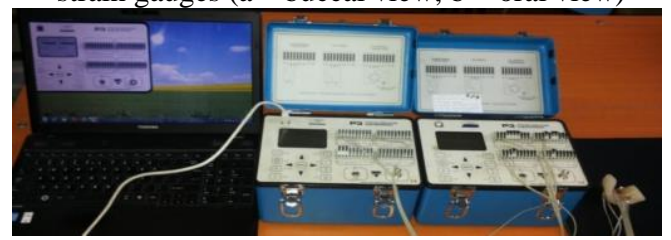

Fig. 8. Strain gauge bridges P3 model (Vishay) 


\section{d. PERIOTEST method}

In order to verify the accuracy of the periodontal ligament simulation procedure, dental mobility was tested with PERIOTEST (Medizintechnik Gulden, Germany) at the level of each tooth, in the middle of the buccal face, with three values per tooth (Fig. 9).

The 'Periotest value' (PTV) depends to some extent on tooth mobility, but mainly on the damping characteristics of the periodontium [18]. The PTV rang from -8 to +50 and can be correlated with the four classes of tooth mobility reported by Miller [19]. The PTV and its correlations to clinical mobility are given in table 1.

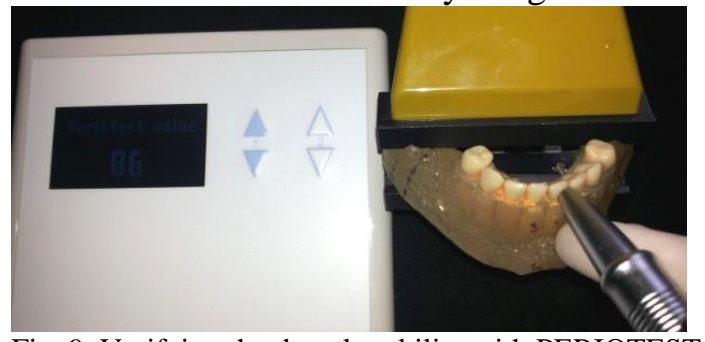

Fig. 9. Verifying the dental mobility with PERIOTEST

Table 1

PTV VS. CLINICAL MOBILITY

\begin{tabular}{|c|c|}
\hline $\begin{array}{c}\text { Periotest } \\
\text { value }\end{array}$ & $\begin{array}{c}\text { Clinical degree of tooth } \\
\text { mobility }\end{array}$ \\
\hline$(-8)-(+9)$ & 0 \\
\hline$(+10)-(+19)$ & I \\
\hline$(+20)-(+29)$ & II \\
\hline$(+30)-(+50)$ & III \\
\hline
\end{tabular}

Initially, the mechanical tests were performed on the original bone model, with normal alveolar bone height (NBH). Subsequently, $5 \mathrm{~mm}$ of acrylate was removed for CIs and $4 \mathrm{~mm}$ for LIs, replicating the bone resorption (BR) from marginal periodontitis, and new Periotest mobility assessment was performed.

\section{e. Compression test of the initial mandibular models}

Compression tests were performed with a WDW-5CE High Performance Electronic Universal Testing Machine (Bairoe, Shanghai, China). With a specially adapted device, the position of the model on the machine table allowed to apply an occlusal load at an angle of $135^{\circ}$ to the long axis of the mandibular teeth, simulating the normal interincisal angle (between upper and lower incisors).

Two loading devices were used to simulate mandibular dynamics so that the force was distributed as follows: (i) at the level of the four incisors - 4I; (ii) at the level of the two central incisors - 2I.

Three compression tests were made for each situation. The loading speed was $0.5 \mathrm{~mm} / \mathrm{min}$, the maximum load being $150 \mathrm{~N}$. The static tests were performed at room temperature $\left(23^{\circ} \mathrm{C}\right)$. Before each test, a 5 minute break was made to allow re-calibration of the gauges, and if this was not done, the manual balance of the gauges (zeroing) was used. The time-force variation was recorded on the WDW50 testing machine, and the specific deformations provided by the SG (in relation to time) were made on the Vishay P3 bridges (Vishay Precision Group, Inc.).

\section{f. Teeth displacement evaluation}

As mechanical comparator, a dial indicator was used throughout the tests allowing measurements with an accuracy of $\pm 0.01 \mathrm{~mm}$. The plunger was positioned in contact with the middle $1 / 3$ of the buccal face of LCI and RLI (Fig. 10).

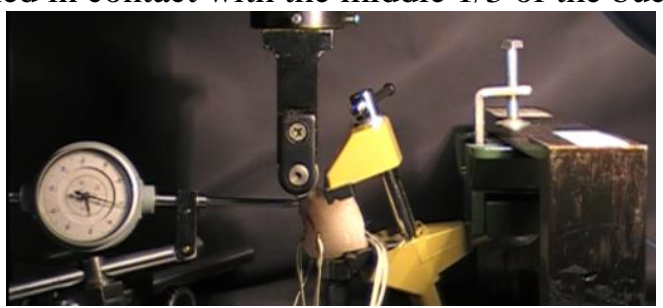

Fig. 10. The probe application on the buccal surface of the lateral incisor 
The models were subjected to three similar loading cycles and the displacement values expressed in mm were read for the four loading forces: $30 \mathrm{~N}, 50 \mathrm{~N}, 100 \mathrm{~N}$ and $150 \mathrm{~N}$, respectively.

\section{g. Statistical analysis}

The collected data were processed with STATISTICA 11.0 (Stat-Soft, Tulsa, OK). The collected strain data was subjected to a factorial analysis of variance (ANOVA) to examine the effect of bone status, mandible surface, load distribution and tooth, and as well as the interaction between these 4 parameters on the strain under 30, 50, 100, and 150 $\mathrm{N}$ loading. All tests were performed at a significance level of 0.05 .

\section{Results and discussions}

Advanced periodontal disease is characterized by a significant reduction of the periodontal support associated with increased dental mobility [20]. Under these conditions, even the physiological occlusal forces may have a negative impact on the bone support, worsening the bone resorption. Since these aspects cannot be clinically evidentiated, in vitro studies are necessary to quantify the impact of occlusal load and periodontal splinting on alveolar bone. For these reasons, reliable mandible replica is necessary, in order to accurate reproduction of the intraoral biomechanical conditions.

It was proved that Periotest is a reliable device to evaluate the tooth mobility. The records made with Periotest device proved to be reproducible, with insignificant statistically variations (Table 2). For incisors with bone resorption, PTVs between 27 and 41 units were obtained, which is accordingly to clinical findings and justify the application of immobilisation systems. As according to a related study, for in vitro experiments a much smaller measurement error than in in vivo experiments is expected [21]. Clinically, there are too many factors that can influence the PTV measurements.

The results for the strains recorded in the bone tissue representing the deformation response of the mandible to occlusal loading are shown in Table 3.

Table 2

THE MEANS (STANDARD DEVIATIONS) OF PTVs

$\begin{array}{cccccccccc}\text { Tooth } & \text { RP } & \text { RC } & \text { RLI } & \text { RCI } & \text { LCI } & \text { LLI } & \text { LC } & \text { LP } \\ \text { Normal bone height } & 1.0(0.2) & -1.0(0.5) & 0.2(0.7) & 0.0(0.3) & 0,1(0.2) & 0.2(0.3) & -0,8(0.2) & 0.1(0.4) \\ \text { Bone resorption } & 1.0(0.2) & -1.0(0.5) & 27.3(1.5) & 34.7(2.5) & 41.3(2.5) & 28(2.0) & -0,8(0.2) & 0.1(0.4) \\ \text { RP = right premolar; } R C=\text { right canine; } \text { RLI = right lateral incisor; } R C I=\text { right central incisor; } \\ \text { LCI = left central incisor; } \text { LLI = left lateral incisor; LC = left canine; LP = left premolar }\end{array}$

Table 3

BONE STRAIN VALUES FOR THE FOUR COMPRESSION LOADS

\begin{tabular}{|c|c|c|c|c|c|c|c|c|c|c|c|c|c|c|c|c|c|}
\hline \multirow{4}{*}{\multicolumn{2}{|c|}{$\begin{array}{l}\text { Load distr. } \\
\text { Bone status } \\
\text { Surface } \\
\text { Tooth }\end{array}$}} & \multicolumn{8}{|c|}{$2 I$} & \multicolumn{8}{|c|}{$4 I$} \\
\hline & & \multicolumn{4}{|c|}{$N B H$} & \multicolumn{4}{|c|}{$B R$} & \multicolumn{4}{|c|}{$N B H$} & \multicolumn{4}{|c|}{$B R$} \\
\hline & & \multicolumn{2}{|c|}{ Buccal } & \multicolumn{2}{|c|}{ Lingual } & \multicolumn{2}{|c|}{ Buccal } & \multicolumn{2}{|c|}{ Lingual } & \multicolumn{2}{|c|}{ Buccal } & \multicolumn{2}{|c|}{ Lingual } & \multicolumn{2}{|c|}{ Buccal } & \multicolumn{2}{|c|}{ Lingual } \\
\hline & & $L I$ & $C I$ & $L I$ & $C I$ & $L I$ & $C I$ & $L I$ & $C I$ & $L I$ & CI & $\boldsymbol{L I}$ & CI & $L I$ & CI & $L I$ & $C I$ \\
\hline \multirow{2}{*}{$30 N$} & Mean & 13.0 & 298.3 & 9.8 & 259.9 & 32.0 & 547.4 & 28.1 & 486.0 & 91.8 & 65.2 & 151.4 & 109.8 & 143.5 & 249.6 & 110.4 & 178.4 \\
\hline & $S D$ & 1.66 & 36.91 & 1.03 & 31.77 & 3.90 & 57.49 & 3.58 & 59.61 & 11.01 & 8.31 & 19.17 & 13.17 & 18.27 & 30.01 & 14.05 & 22.42 \\
\hline \multirow{2}{*}{$50 \mathrm{~N}$} & Mean & 23.0 & 399.6 & 16.0 & 360.6 & 39.0 & 730.2 & 37.0 & 647.4 & 123.4 & 204.8 & 92.4 & 153.3 & 201.8 & 356.6 & 156.8 & 261.7 \\
\hline & $S D$ & 2.65 & 46.02 & 1.77 & 41.53 & 4.49 & 82.49 & 4.26 & 72.84 & 13.49 & 23.58 & 9.91 & 17.00 & 23.24 & 41.07 & 18.06 & 30.14 \\
\hline \multirow{2}{*}{$100 \mathrm{~N}$} & Mean & 38.4 & 800.4 & 23.2 & 680.4 & 53.9 & 1389.7 & 41.3 & 1181.7 & 230.5 & 421.4 & 194.4 & 337.2 & 364.6 & 661.1 & 313.7 & 540.9 \\
\hline & $S D$ & 3.92 & 90.17 & 2.36 & 76.67 & 6.21 & 158.09 & 4.25 & 134.51 & 25.48 & 47.18 & 21.55 & 37.91 & 41.99 & 74.92 & 36.13 & 61.58 \\
\hline \multirow{2}{*}{$150 \mathrm{~N}$} & Mean & 48.9 & 1169.5 & 37.1 & 1014.4 & 64.3 & 1710.3 & 52.3 & 1527.5 & 329.6 & 615.7 & 281.4 & 509.9 & 541.7 & 962.1 & 471.4 & 812.8 \\
\hline & $S D$ & 5.64 & 133.41 & 4.03 & 114.45 & 6.86 & 193.66 & 5.59 & 174.01 & 37.97 & 70.33 & 31.38 & 57.96 & 61.99 & 109.05 & 52.85 & 92.59 \\
\hline
\end{tabular}


The results of factorial ANOVA for data obtained with the 4 loadings $(30,50,100$ and 150N) for load distribution, bone status, mandibular surface and tooth regions are presented in Table 4.

Table 4

\begin{tabular}{|c|c|c|c|c|c|c|c|c|c|c|c|c|c|}
\hline & \multicolumn{4}{|c|}{$30 \mathrm{~N}$} & \multicolumn{3}{|c|}{$50 \mathrm{~N}$} & \multicolumn{3}{|c|}{$100 \mathrm{~N}$} & \multicolumn{3}{|c|}{$150 \mathrm{~N}$} \\
\hline & $d f$ & SS/MS & F & $\mathbf{p}$ & SS/MS & $\mathbf{F}$ & p & SS/MS & $\mathbf{F}$ & p & SS/MS & F & $\mathbf{p}$ \\
\hline Intercept & 1 & 4330433 & 5808.89 & $<.001$ & 8137427 & 6323.55 & $<.001$ & 29752770 & 6396.58 & $<.001$ & 57938751 & 6784.33 & $<.001$ \\
\hline$\{1\} L D$ & 1 & 185709 & 249.11 & $<.001$ & 277205 & 215.41 & $<.001$ & 738079 & 158.68 & $<.001$ & 680489 & 79.68 & $<.001$ \\
\hline$\{2\} B S$ & 1 & 338731 & 454.38 & $<.001$ & 629043 & 488.83 & $<.001$ & 1865246 & 401.01 & $<.001$ & 2565536 & 300.41 & $<.001$ \\
\hline$\{3\} M b S$ & 1 & 43888 & 58.87 & $<.001$ & 70089 & 54.47 & $<.001$ & 235670 & 50.67 & $<.001$ & 304091 & 35.61 & $<.001$ \\
\hline$\{4\} T$ & 1 & 1796174 & 2409.41 & $<.001$ & 3307454 & 2570.21 & $<.001$ & 12706872 & 2731.87 & $<.001$ & 23732673 & 2778.97 & $<.001$ \\
\hline$L D * B S$ & 1 & 34844 & 46.74 & $<.001$ & 35531 & 27.61 & $<.001$ & 102873 & 22.12 & $<.001$ & 615 & 0.07 & 0.789 \\
\hline$L D * M b S$ & 1 & 2428 & 3.26 & 0.073 & 4715 & 3.66 & 0.058 & 2331 & 0.50 & 0.480 & 79 & 0.01 & 0.924 \\
\hline$B S^{*} M b S$ & 1 & 2011 & 2.70 & 0.103 & 5221 & 4.06 & 0.046 & 10440 & 2.24 & 0.137 & 4907 & 0.57 & 0.450 \\
\hline$L D * T$ & 1 & 851543 & 1142.27 & $<.001$ & 1477916 & 1148.48 & $<.001$ & 5190947 & 1116.01 & $<.001$ & 8744278 & 1023.91 & $<.001$ \\
\hline$B S * T$ & 1 & 145154 & 194.71 & $<.001$ & 274104 & 213.00 & $<.001$ & 874412 & 187.99 & $<.001$ & 907906 & 106.31 & $<.001$ \\
\hline$M b S^{*} T$ & 1 & 11947 & 16.03 & $<.001$ & 18913 & 14.70 & $<.001$ & 98150 & 21.10 & $<.001$ & 114171 & 13.37 & $<.001$ \\
\hline$L D * B S * M b S$ & 1 & 85 & 0.11 & 0.737 & 192 & 0.15 & 0.700 & 672 & 0.14 & 0.704 & 796 & 0.09 & 0.761 \\
\hline$L D * B S * T$ & 1 & 76234 & 102.26 & $<.001$ & 120660 & 93.76 & $<.001$ & 422996 & 90.94 & $<.001$ & 338911 & 39.68 & $<.001$ \\
\hline$L D * M b S * T$ & 1 & 878 & 1.18 & 0.280 & 1008 & 0.78 & 0.378 & 18847 & 4.05 & 0.046 & 17687 & 2.07 & 0.153 \\
\hline$B S * M b S * T$ & 1 & 1158 & 1.55 & 0.215 & 3438 & 2.67 & 0.105 & 7009 & 1.51 & 0.222 & 1349 & 0.16 & 0.692 \\
\hline $1 * 2 * 3 * 4$ & 1 & 0 & 0.00 & 1.000 & 213 & 0.17 & 0.685 & 2699 & 0.58 & 0.448 & 19 & 0.00 & 0.963 \\
\hline Error & 128 & $\begin{array}{l}95422 / \\
745\end{array}$ & & & $\begin{array}{c}164716 / \\
1287\end{array}$ & & & $\begin{array}{c}595373 / \\
4651\end{array}$ & & & $\begin{array}{c}1093131 / \\
8540\end{array}$ & & \\
\hline
\end{tabular}

$L D=$ load distribution $; B S=$ bone status; $M b S=$ mandibular surface $;=$ tooth $; d=$ degrees of freedom;

$S S=$ sum of squares; $M S-$ mean square; $F=$ calculated $F$

The factorial ANOVA indicated significant differences between the four factors (load distribution, bone status, mandibular surface; tooth; $\mathrm{P}<0.001$ ), irrespective of load level. For the 2-factor interactions, the following interactions were significant for all load values $(\mathrm{P}<0.001)$ : load distribution and bone status, load distribution and tooth, bone status and tooth, and mandibular surface and tooth. Of the 3 -factor interactions, only the load distribution, bone status and tooth interaction was statistical significant irrespective of load level.

When force is applied to the central incisors, the observed deformation values are $60 \%$ higher than when the force is applied equally to the four incisors. The mean strain values for the samples with bone resorption were higher than for those with normal bone height. The mean strain values measured on the buccal surfaces were significantly higher than on the lingual surfaces. The values obtained at the central incisor region were significantly higher than for the lateral incisor region.

As for tooth horizontal displacements recorded with the mechanical comparator placed in contact with LCI and RLI, the average values obtained are shown in Table 5. Similar to bone strain, the displacement values of teeth in the anterior mandible region were directly proportional to the values of the four loading forces.

Table 5

HORIZONTAL DISPLACEMENT VALUES AT THE LEVEL OF RIGHT LATERAL INCISOR AND LEFT CENTRAL INCISOR RECORDED BY THE COMPARATOR (mm)

\begin{tabular}{|c|c|c|c|c|c|c|c|c|c|c|c|c|c|}
\hline \multirow{3}{*}{\multicolumn{2}{|c|}{$\operatorname{Load}(\mathbf{N})$}} & \multicolumn{12}{|c|}{ Force distribution } \\
\hline & & \multicolumn{2}{|c|}{$\mathrm{NBH}_{4 \mathrm{I}}$} & \multicolumn{2}{|c|}{$\mathrm{NBH}_{2 \mathrm{I}}$} & \multicolumn{2}{|c|}{$\mathrm{NBH}_{\mathbf{c}}$} & \multicolumn{2}{|c|}{$\mathbf{R B}_{4 \mathbf{I}}$} & \multicolumn{2}{|c|}{$\mathbf{R B}_{2 I}$} & \multicolumn{2}{|c|}{$\mathbf{R B C}$} \\
\hline & & RLI & LCI & RLI & LCI & RLI & LCI & RLI & LCI & RLI & LCI & RLI & LCI \\
\hline \multirow{2}{*}{30} & Mean & 0 & 0 & 0 & 0.01 & 0 & 0 & 0.032 & 0.05 & 0.1 & 0.45 & 0 & 0 \\
\hline & $S D$ & 0 & 0 & 0 & 0.0018 & 0 & 0 & 0.0024 & 0.0033 & 0.0074 & 0.0615 & 0 & 0 \\
\hline \multirow{2}{*}{50} & Mean & 0.008 & 0.010 & 0.002 & 0.033 & 0 & 0 & 0.21 & 0.25 & 0.29 & 0.95 & 0.007 & 0 \\
\hline & SD & 0.0013 & 0.0006 & 0.0002 & 0.0041 & 0 & 0 & 0.0352 & 0.0169 & 0.0157 & 0.1463 & 0.0009 & 0 \\
\hline \multirow{2}{*}{100} & Mean & 0.01 & 0.015 & 0.003 & 0.043 & 0 & 0.008 & 0.7 & 0.96 & 0.5 & 1.28 & 0.07 & 0.05 \\
\hline & SD & 0.0026 & 0.0009 & 0.0005 & 0.0071 & 0 & 0.0012 & 0.0953 & 0.0887 & 0.0692 & 0.3072 & 0.0055 & 0.0064 \\
\hline \multirow{2}{*}{150} & Mean & 0.036 & 0.040 & 0.005 & 0.055 & 0.002 & 0.01 & 1.04 & 1.17 & 0.72 & 1.55 & 0.16 & 0.2 \\
\hline & SD & 0.0057 & 0.0033 & 0.0006 & 0.0082 & 0.0003 & 0.0024 & 0.0864 & 0.0230 & 0.0576 & 0.1007 & 0.0332 & 0.0311 \\
\hline
\end{tabular}

$R L I=$ right lateral incisor, $L C I=$ left central incisor, $N B H=$ normal alveolar bone height, $B R=$ bone resorption, $S D=$ standard deviation MATERIALE PLASTICE $\$ 56$ no. 4 \2019 
In a previous study, a self-curing acrylic resin model (Duracryl Plus, Spofa Dental, Czech Republic) used as a replica for the mandible bone was validated [22]. In this respect, the elastic constants of the bone (Young's modulus and Poisson's ratio), essential for simulating an experimental model, were considered.

Various values for the Young's modulus and Poisson's ratio of the trabecular bone in the anterior mandibular region were reported in literature: $1.37 \mathrm{GPa}$ and 0.3 [23, 24], $1.5 \mathrm{GPa}$ and 0.29 [25], $2.5 \mathrm{GPa}$ and 0.3 [26]. Additionally, different materials used as a replica for mandibular bone in vitro study were reported: acrylic resin, epoxy resin, polyurethane resin, polystyrene resin [16, 19, 27, 28]. For this study, the self-curing acrylic resin used had a volumetric ratio of 3 parts powder to 1.5 parts of liquid, and presented elastic characteristics similar to those of the spongy bone from the anterior region of the mandible, as well as an average viscosity. These aspects allowed the pouring into complex forms, a proper work time and a low contraction $[22,29]$.

Another parameter that required a precise reproduction was the periodontal ligament because it plays an important role in the transmission and distribution of occlusal load in the alveolar bone. The mandibular models used for laboratory studies incorporating materials simulating the periodontal ligament significantly alter the pattern of fracture compared to models without periodontal ligament simulation [30]. In various studies, an attempt was made to simulate the periodontal ligament by covering the roots with a layer of different self-curing materials. Due to lack of standardization, various materials have been used for this purpose: condensation silicones [31,32], addition silicones [33, 34], polyethers [35-37] and waxes [38]. Sterzenbach et al. have conducted a study on simulation of in vitro dental mobility and compared three impression materials: polyurethane, polyether and polysiloxane. The authors concluded that the most appropriate method of simulation of dental mobility is the use of a self-curing acrylic resin and a polysiloxane [39]. In another study, four materials were compared: two acrylic materials for rebasing - Durabase (Reliance Dental MFG, Co.) and Soft Liner (GC Corporation) and two impression materials - President Plus (Coltene) silicone, Prestige L (Vanini Dental Industry). These were analysed according to two parameters: deformation and return to the initial form. The conclusion was that addition silicone can best simulate the characteristics of the periodontal ligament [40]. In the present study, a fluid condensation silicone was used to reproduce the periodontal ligament (Oranwash, Zermack, Lot No: 192139).

The occlusal forces values are according to the reported data in the literature for the anterior mandible region, between 40 and $200 \mathrm{~N}[12,41]$. Intermediate loading values $(30 \mathrm{~N}, 50 \mathrm{~N}, 100 \mathrm{~N}, 150 \mathrm{~N})$ were used to test the influence of small, medium and close loads on the reported physiological limit. Although occlusal forces in the anterior region are usually considered to be relatively smaller, larger forces may also occur in this area, for example, due to the loss of dento-periodontal units in the posterior support region that results in the occlusal forces concentration at the level frontal teeth $[42,43]$. The applied forces were non-destructive, falling within physiological limits, the purpose of the study being to quantify deformations at the bone level and not to assess the breaking force and fracture pattern of various dental fixtures.

The clinical relevance of strain values is that they describe the biomechanical behaviour of supporting dental tissue subjected to occlusal forces deformation. Even if they are indirectly determined, on a mandible replica that did not simulate all the live tissues characteristics and did not have the exact same shape and dimensions, these recorded strain values were similar to those reported by Soares et al. [12] and Cehreli et al. [18].

High strains in supporting bone tissue may cause immediate damage to the bone. Even small, cyclically applied forces over a longer period can cause a fatigue phenomenon or interfere with tissue healing processes, also due to the small size of the bone structure in this region. In all simulated situations, higher values of deformations on the vestibular surface were observed, as reported by Soares et al., which can be explained by a lower thickness of the buccal bone versus the lingual bone [12]. Periodontal disease reduces the bone support of teeth leading to increased strain. In this context, even the physiological loads may become harmful. Periodontal splinting contributes to distributing the forces to adjacent teeth, reducing the impact on the already suffering supporting bone tissues. Lowering the induced strain permits the reparatory bone processes to occur in a context of a reduced irritation.

\section{Conclusions}

The vitro experiments are generally disregarding the innervations of teeth, the viscos-elastic features of the periodontal ligament, endo-periodontal pathology, the blood, the humidity or other tissue characteristics [17] and the physical properties of the bone could only be partially simulated. These features can be modified by dynamic occlusal load which is characteristic for oral environment, leading to a different biomechanical behaviour. Our model showed that the loss of bone support and the increasing occlusal loading resulted in significantly greater displacement of the loaded teeth and their adjacent ones, reflecting the clinical findings. The displacement in the central incisor region was significantly higher than in the lateral incisor region. Within the study's limitations, the mandibular replica obtained can be used as a starting point for further biomechanical studies in different dental domains like orthodontics, periodontology and fixed and removable prosthodontics. 


\section{References}

1.SERIO, F.G., HAWLEY, C.E., Dent. Clin. North. Am., 43, no. 1, 1999, p. 37.

2.SERIO, F.G., Dent. Clin. North. Am., 43, no. 1, 1999, p. 1.

3.HALLMON, W.W., HARREL, S.K., Periodontol. 2000, 34, no. 1, 2004, p. 151

4.FORABOSCO, A., GRANDI, T., COTTI, B., Minerva Stomatol. 55, no. 3, 2006, p. 87.

5.BERNAL, G., CARVAJAL, J.C., MUNOZ-VIVEROS, C.A.J., Contemp. Dent. Pract., 3, no. 4, 2002, p. 10.

6.JUDGE, R.B., PALAMARA, J.E., TAYLOR, R.G. et al., J. Prosthet. Dent., 90, no. 1, 2003, p. 92.

7.VIERIU, R.M., TANCULESCU, O., MOCANU, F., DOLOCA, A., MARTU, S., Mat. Plast., 52, no. 2, 2015, p. 266

8.IOVAN, G., STOLERIU, S., PANCU, G., NICA, I., SANDU, A.V., ANDRIAN, S., TANCULESCU, O., Mat. Plast., 54, no. 2, 2017, p. 375

9.CENGIZ, S.B., ATAC, A.S., CEHRELI, Z.C., Dental Traumatology, 22, 2006, p. 133.

10.SOARES, P.B., FERNANDES NETO, A.J., MAGALHÃES, D. et al., Arch. Oral Biol., 56, 2011, p. 1373.

11.GERAMY, A., MOSLEMI, N., RETROUVEY, J.M. et al., Int. J. Clin. Dent., 6, no. 2, 2013, p. 137.

12.PERRY, C.C., Strain, 23, no. 4, 1987, p. 155.

13.BARSANESCU, P.D., BEJAN, L., MOCANU, F., BITCA, C., Tensometrie electrică rezistivă aplicată la materiale compozite. Iaşi, Ed. Tehnopress, 2004, p. 145-150, 153, 157, 161, 166, 169, 172-174, 178, 180.

14.HEKIMOGLU, C., ANIL, N., CEHRELI, M.C., J. Prothet. Dent., 92, no. 5, 2004, p. 441.

15.ASUNDI, A., KISHEN, A., Arch. Oral Biol., 45, no. 7, 2000, p. 543.

16.CEHRELI, M.C., AKKOCAOGLU, M., COMERT, A., TEKDEMIR, I., AKCA, K., Clin. Oral Implants. Res., 16, no. 5, 2005 p. 540.

17.KARL, M., ROSCH, S., GRAEF, F., TAYLOR, T.D., HECKMANN, S.M., J. Prosthet. Dent., 93, no. 4, 2005, p. 324

18.ROSENBERG, D., QUIRYNEN, M., VAN STEENBERGHE, D., NAERT, I.E., TRICIO, J., NYS, M., Quintessence Int., 26, no. 3 , 1995 , p. 191. 19.MILLER JR, P. D., Int. J. Periodont. Rest., 5, no. 2, 1985, p. 8.

20.IOANID, N., IFTENI, G., GRADINARU, I., MARTU, S., TANCULESCU, O., Rom. J. Oral Rehab., 8, no. 2, 2016, p. 111

21.LACHMANN, S., JAGER, B., AXMANN, D., GOMEZ-ROMAN, G., GROTEN, M., WEBER, H., Clin. Oral Implants Res. 17, 2006, p. 75.

22.VIERIU, R.M., TANCULESCU, O., MOCANU, F., ANICULAESA, A., DOLOCA, A., LUCHIAN, I., MARTU, S., Rom. J. Oral Rehab., 7, no. 2,2015 , p. 74

23.MENICUCCI, G., MOSSOLOV, A., MOZZATI, M. et al., Clin. Oral Implants Res., 13, no. 3, 2002, p. 334.

24.MEIJER, H.J., STARMANS, F.J., STEEN, W.H., BOSMAN, F., Arch. Oral Biol., 38, no. 6, 1993, p. 491.

25.ZARONE, F., APICELLA, A., NICOLAIS, L. et al., Clin. Oral Implants Res., 14, no. 1, 2003, p. 103.

26.PIERRISNARD, L., HURE, G., BARQUINS, M., CHAPPARD, D., Int. J. Oral Maxillofac. Implant, 17, no. 3, 2002 , p. 353.

27.MIYASHIRO, M., SUEDAM, V., MORETTI NETO, R.T. et al., J. Appl. Oral Sci., 19, no. 3, 2011, p. 244

28.DAHAB, I.A., EL-GENDY, A.A., ELTORKY, I.R., Tanta Dental Journal, 12, no. 1, 2015, p. 7.

29.ZAHARIA, A., PLESCAN GHISMAN, V., STEFANESCU, C.L., MUSAT, V., Rev. Chim.(Bucharest), 67, no. 10, p. 2022

30.SOARES, C.J., PIZI, E.C., FONSECA, R.B., MARTINS, L.R., Braz. Oral Res., 19, no. 1, 2005, p. 11.

31.AKKAYAN, B., J. Prosthet. Dent., 92, 2004, p. 155.

32.CECCHIN, D., FARINA, A.P., GUERREIRO, C.A., CARLINI-JUNIOR, B., J. Oral Rehabil., 37, 2010, p. 116.

33.SIRIMAI, S., RIIS, D.N., MORGANO, S.M., J. Prosthet. Dent., 81, 1999, p. 262.

34.ABE, Y., NOGAMI, K., YASUDA, K. et al., Open Journal of Stomatology, 4, 2014, p. 303.

35.ROSENTRITT, M., BEHR, M., LANG, R., HANDEL, G., Dent. Mater., 16, 2000, p. 159.

36.CHOY, K., KIM, K.H., BURSTONE, C.J., Eur. J. Orthod., 28, 2006, p. 471.

37.SOARES, C.J., RAPOSO, L.H., SOARES, P.V. et al., J. Prosthodont., 19, 2010, p. 130.

38.KINZINGER, G.S., DIEDRICH, P.R., Angle Orthod., 78, 2008, p. 676.

39.STERZENBACH, G., KALBERLAH, S., BEUER, F. et al., Acta Odontol. Scand., 69, no. 5, 2011, p. 316.

40.BROSH, T., PORAT, N., VARDIMON, A.D., PILO, R., J. Oral Rehabil., 38, no. 12, 2011, p. 929.

41.HELLSING, G., J. Oral Rehabil., 7, no. 5, 1980, p. 403.

42.TANCULESCU, O., DOLOCA, A., VIERIU, R.M., MOCANU, F., MARTU, S., IOVAN, G., IFTENI, G., IOANID, N., Rev. Chim. (Bucharest), 67, no. 1,2016 , p. 96.

43.GIBBS, C.H., ANUSAVICE, K.J., YOUNG, H.M. et al., J. Prosthet. Dent., 88, no. 5, 2002, p. 498.

$\overline{\text { Manuscript received: } 26.11 .2019}$ 